\title{
Synthesis of hydantoin and thiohydantoin related compounds from benzil and study of their cytotoxicity
}

\author{
A. Kashem Liton and M. Rabiul Islam \\ Department of Chemistry, Jahangirnagar University, Savar, Dhaka 1342, Bangladesh.
}

\begin{tabular}{|c|c|}
\hline \multicolumn{2}{|l|}{ Article Info } \\
\hline Received: & 15 December 2005 \\
\hline Accepted: & 20 January 2006 \\
\hline Available Online: & 3 January 2008 \\
\hline \multicolumn{2}{|c|}{ DOI: 10.3329/bjp.v1i1.481 } \\
\hline \multicolumn{2}{|c|}{$\begin{array}{l}\text { Cite this article: } \\
\text { Liton AK, Islam MR. Synthesis of } \\
\text { hydantoin and thiohydantoin related } \\
\text { compounds from benzil and study of } \\
\text { their cytotoxicity. Bangladesh J Phar- } \\
\text { macol. 2006; 1: 10-15. }\end{array}$} \\
\hline
\end{tabular}

\section{Abstract}

Condensation of benzil (1) with urea, monophenyl urea and diphenyl urea in the presence of absolute ethanol using $30 \%$ aqueous $\mathrm{NaOH}$ gave the products $1 \mathrm{a}, \mathbf{1 b}$ and $1 \mathrm{c}$ respectively and also with thiourea, monomethyl thiourea, dimethyl thiourea and diethyl thiourea the products $2 a, 2 b, 2 c$ and $2 d$ were obtained. Methylation of the product, $2 \mathrm{a}$ in the presence of dimethyl formamide (DMF) using $\mathrm{K}_{2} \mathrm{CO}_{3}$ formed 2 . The compounds $1 \mathbf{b}, 1 \mathrm{c}, \mathbf{2 b}, \mathbf{2 c}$ and 2 showed highly cytotoxic activity and the compounds $\mathbf{1 a}, \mathbf{2 a}, \mathbf{2} \mathbf{d}$ showed relatively low cytotoxic activity against brine shrimp lethality bioassay.

\section{Introduction}

Several types of substituted isatin heterocyclic derivatives were synthesized and found cytotoxic activity of these compounds by screening tests (Islam et al., 2001a; Islam et al., 2001b; Lingcon et al., 2001). Methyl and bromine groups in the benzene ring of isatin, $\Delta^{2}-1,3,5-$ thiadiaozolines show more cytotoxic activity. For this interest, the title compounds have been synthesized for screening tests whether they show reasonable lethal effect on brine shrimp or not. We report to see herein the results of the synthesis of the mentioned compounds (Scheme 1), spectral characterization and their cytotoxic effects by brine shrimp lethality bioassay (Anderson et al., 1999).

\section{Materials and Methods}

Melting points are not corrected. IR spectra recorded on a Shimadzu DR 8001 FT-IR spectrometer, NMR spectra on a WP 200 spectrometer using TMS as internal standard and mass spectra on an MS Kratas mass spectrometer.

\section{Preparation of mono- and diphenyl urea}

Mono-phenyl urea and diphenyl urea were prepared from aniline hydrochloride and urea following the reported procedure (Furniss et al., 1998).

\section{Preparation of 5,5-diphenylhydantoin (1a) (Muccioli et al., 2003)}

Benzil, 1 (0.8 g, $3.8 \mathrm{mmol} / \mathrm{L})$ was placed in a $100 \mathrm{~mL}$ round-bottomed flask with urea, $(0.4 \mathrm{~g}, 6.7 \mathrm{mmol} / \mathrm{L})$ in the molar ratio of ca 1:2. Absolute ethanol $(12 \mathrm{~mL})$ and $30 \%$ aqueous sodium hydroxide $(2.5 \mathrm{~mL})$ were added to these reactants. Boiling chips were also added to this solution and a condenser was attached after wrapping the ground glass joint with Teflon tape, and was heated $\left(110-120^{\circ} \mathrm{C}\right)$ the mixture under reflux (2 hours). The reaction mixture was cooled before adding $15 \mathrm{~mL}$ of water. The solution was not clear, so the suspended solids were removed by filtration. Then the clear solu- 


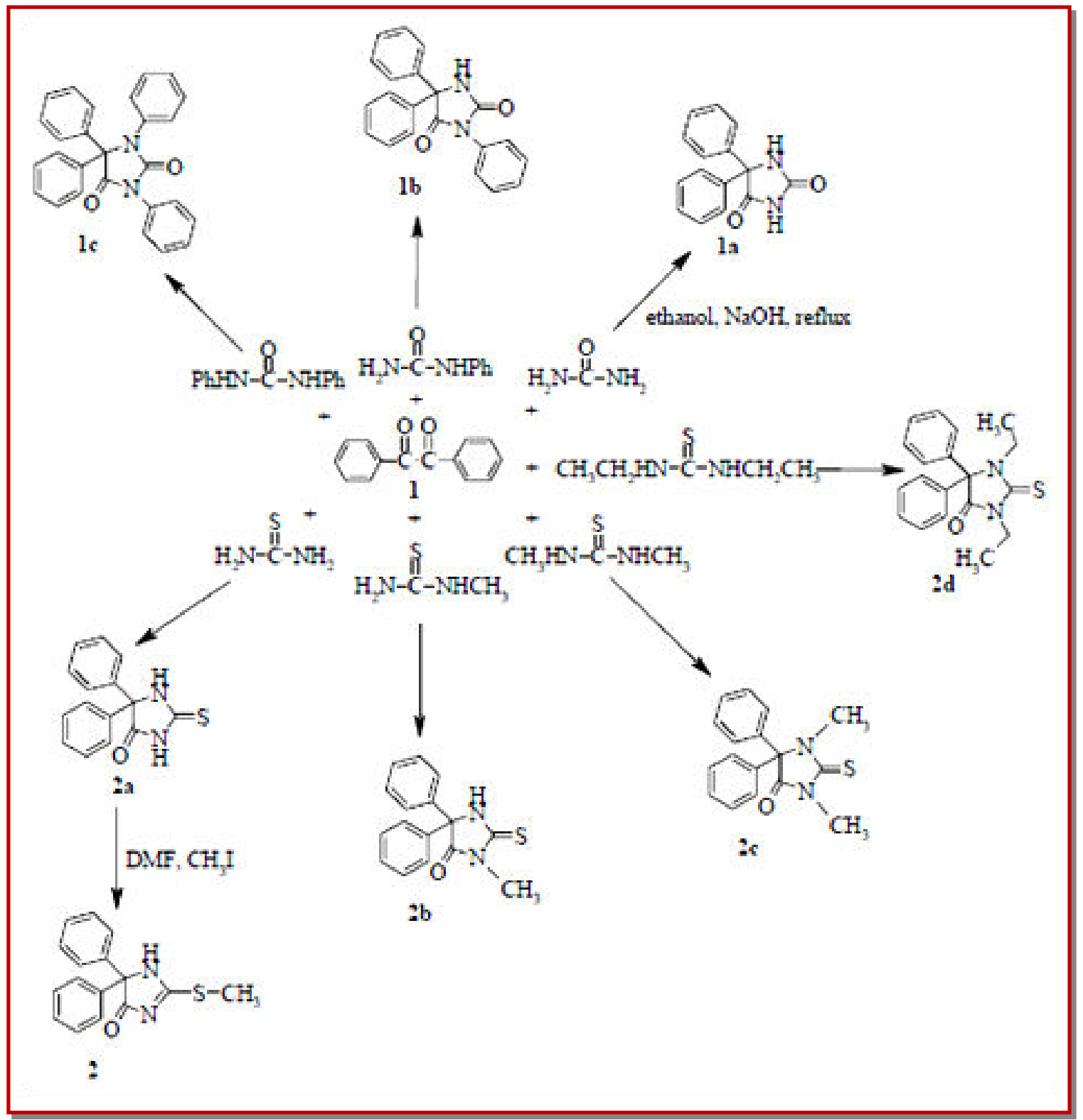

Scheme 1

tion was cautiously acidified with concentrated hydrochloric acid and the product was collected by vacuum filtration and washed thoroughly with water.

Then the product, 1a was recrystallized by ethanol, dried, the m.p. $294-295^{\circ} \mathrm{C}$ and yields $0.750 \mathrm{~g}(80 \%)$. IR: v Nujol $\left(\mathrm{cm}^{-1}\right) 3271$ (s, vN-H amide, CO-NH-CO); 3204 (s, $\mathrm{vN}-\mathrm{H}$ amide, $\left.\mathrm{CO}-\mathrm{NH}-\mathrm{CPh}_{2}\right) ; 3055$ (m, vC-H aromatic); 1772 (s, vC=O amide, NH-CO-CPh $)$; 1741 (s, vC=O amide, NH-CO-NH); 1597, 1541, 1508 (s, vC=C, aromatic). ${ }^{1} \mathrm{H}-\mathrm{NMR}$ (DMSO): $\delta 10.10(\mathrm{~s}, 1 \mathrm{H}, \mathrm{NH}, \mathrm{CO}-$ $\mathrm{NH}-\mathrm{CO}) ; \delta 9.10$ (s, 1H, NH, CO-NH-CPh $) ; \delta$ 7.80-7.00 (m, 10H, C-H, aromatic). ${ }^{13} \mathrm{C}-\mathrm{NMR}$ (DMSO): $\delta 175.19$ (C

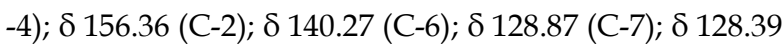
(C-8); $\delta 126.93$ (C-9); $\delta 70.56$ (C-5). Mass: $\mathrm{m} / \mathrm{z}$ (\% of relative intensity) $252\left(\mathrm{M}^{+} .3 \%\right), 176(30 \%), 154(100 \%)$, $128(3 \%), 77(15 \%), 51(8 \%)$, and $39(10 \%)$. The molecular ion peak appears at $\mathrm{m} / \mathrm{z} 252$ due to $\mathrm{C}_{15} \mathrm{H}_{12} \mathrm{~N}_{2} \mathrm{O}_{2}$.

\section{Preparation of 3,5,5-triphenyl hydantoin (1b)}

Benzil, 1; $(0.148 \mathrm{~g}, 0.70 \mathrm{mmol} / \mathrm{L})$ and the monophenylurea; $(0.298 \mathrm{~g}, 1.40 \mathrm{mmol} / \mathrm{L})$ in the molar ratio of ca $1: 2$ were refluxed in the absolute ethanol and the procedure for $\mathbf{1 b}$ was similar to that of the compound, 1a. The product, 1-a1 was colorless solid; m.p. $172-173^{\circ} \mathrm{C}$ having 
yields $0.077 \mathrm{~g}, 50 \%$. IR: v Nujol $\left(\mathrm{cm}^{-1}\right) 3220$ (s, vN-H amide); 3055 (m, vC-H aromatic); 1716 (s, vC=O amide, $\mathrm{NPh}-\mathrm{CO}-\mathrm{C}-\mathrm{Ph}_{2}$ ); 1637 (s, vC=O amide, NH-CO-NPh); 1595, 1541, 1508 (vC=C, aromatic). ${ }^{1} \mathbf{H}-\mathrm{NMR}$ (DMSO): $\delta$ 9.40 (s, 1H, NH, amide); $\delta$ 7.80-7.40 (m, 15H, C-H, aromatic). ${ }^{13} \mathrm{C}-\mathrm{NMR}$ (DMSO): $\delta 173.06$ (C-4); $\delta 154.32$ (C -2); $\delta 141.99$ (C-10); $\delta 140.60$ (C-6); $\delta 129.05$ (C-7) $\delta$

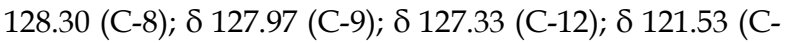
13); $\delta 117.70$ (C-11); 68.70 (C-5). Mass: $\mathrm{m} / \mathrm{z}$ (\% of relative intensity) $328\left(\mathrm{M}^{+} .3 \%\right), 176$ (25\%), 154 (100\%), 136 (68\%), $120(12 \%), 55(27 \%), 43$ (26\%). The molecular ion peak appears at $\mathrm{m} / \mathrm{z} 328$ due to $\mathrm{C}_{21} \mathrm{H}_{16} \mathrm{~N}_{2} \mathrm{O}_{2}$.

\section{Preparation of 1,3,5,5-Tetraphenyl hydantoin (1c)}

Benzil 1; (0.148 $\mathrm{g}, 0.70 \mathrm{mmol} / \mathrm{L})$ and the above 1,3diphenylurea, a3; $(0.298 \mathrm{~g}, 1.40 \mathrm{mmol} / \mathrm{L})$ in the molar ratio of ca 1:2 were refluxed in the absolute ethanol and the procedure of 1c was similar to that of the compound, 1a. The product, 1c was off white powder. It was recrystallized in methanol, dried and m.p. 163$165^{\circ} \mathrm{C}$ and yields were $0.07 \mathrm{~g}, 42 \%$. IR: $\mathrm{v}^{\mathrm{Nujol}}\left(\mathrm{cm}^{-1}\right) 3110$ (w, vC-H aromatic); 1716 (s, vC=O amide, NPh-CO$\mathrm{CPh}_{2}$ ); 1635 (s, vC=O amide, NPh-CO-NPh); 1595, 1541, 1508 (vC=C, aromatic). ${ }^{1} \mathbf{H}-\mathbf{N M R}$ (DMSO): $\delta$ 7.20-6.70 (m, 20H, C-H, aromatic). ${ }^{13} \mathrm{C}-\mathrm{NMR}$ (DMSO): $\delta 173.10$ (C -4); $\delta 154.25$ (C-2); $\delta 141.88$ (C-10); $\delta 140.60$ (C-6); $\delta$

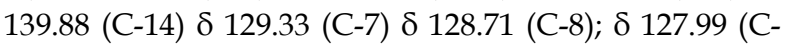

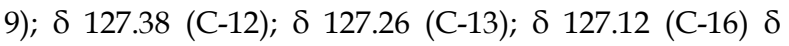
121.60 (C-17); $\delta 117.73$ (C-11); $\delta 109.48$ (C-15) $\delta 69.50$ (C5). Mass: $\mathrm{m} / \mathrm{z}$ (\% of relative intensity) $404\left(\mathrm{M}^{+} .3 \%\right), 369$ (75\%), 347(68\%), 302 (15\%), 259 (7\%), 233 (12\%), 211 (100\%), 182 (92\%), 136 (29\%), 93 (41\%). The molecular ion peak appears at $\mathrm{m} / \mathrm{z} 404$ due to $\mathrm{C}_{27} \mathrm{H}_{20} \mathrm{~N}_{2} \mathrm{O}_{2}$.

\section{Preparation of 5,5-diphenyl-2-thiohydantoin (2a)}

The compound, 2a was prepared from Benzil, 1; (0.80 g, $3.81 \mathrm{mmol} / \mathrm{L})$ and thiourea; (0.58 $\mathrm{g}, 7.63 \mathrm{mmol} / \mathrm{L})$ following the procedure of $\mathbf{1 a}$. The product was recrystallized in ethanol, m.p. $234-235^{\circ} \mathrm{C}$ yielded 0.595 g, 94\%. IR: v Nujol (cm-1) 3255 (s, b, vN-H amide, CO-NHCS); 3135 (b, vN-H, amide, CPh $2-\mathrm{NH}-\mathrm{CS}$ ); 3010 (s, C-H aromatic); 1749 (s, vC=O amide); 1558, 1541, 1508 (vC=C, benzene); 1215 (s, vC=S). ${ }^{1}$ H-NMR (DMSO): $\delta$ 7.80-7.60 (m, 10H, C-H, aromatic), $\delta 1.10-1.12(1 \mathrm{H}, \mathrm{SH})$. 13C-NMR (DMSO): $\delta 181.65$ (C-4); $\delta 175.54$ (C-2); $\delta$

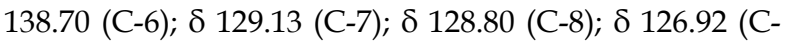
9); 73.92 (C-5). Mass: $\mathrm{m} / \mathrm{z}$ (\% of relative intensity) 268 (M+12\%), 182 (18\%), 154 (100\%), 136 (59\%), 120 (12\%), 107 (19\%), 77 (17\%), 57 (27\%), 43 (23\%). The molecular ion peak appears at $\mathrm{m} / \mathrm{z} 268$ due to $\mathrm{C}_{15} \mathrm{H}_{12} \mathrm{~N}_{2} \mathrm{OS}$.
Preparation of 3-methyl-5, 5-diphenyl-2-thiohydantoin (2b)

Benzil, 1; (0.84 g, $4.00 \mathrm{mmol} / \mathrm{L})$ with methylthiourea $(0.72 \mathrm{~g}, 8.00 \mathrm{mmol} / \mathrm{L})$ in the molar ratio of ca 1:2 were refluxed in ethanol and the procedure for the compound, $\mathbf{2} \mathbf{b}$ is similar to that of the compound, $\mathbf{1 a}$. The product was recrystallized in ethanol; m.p. 182$183^{\circ} \mathrm{C}$ having yields $1.0 \mathrm{~g}, 94 \%$. IR: $\mathrm{v}^{\mathrm{Nujol}}\left(\mathrm{cm}^{-1}\right) 3250$ (b, vN-H thiamide); 3110 (s, w, vC-H aromatic); 2950, 2900 (s, vC-H, aliphatic), 1716 (s, vC=O amide); 1595, 1541, 1508 (vC=C, aromatic); 1215 (s, vC=S). 1 H-NMR (DMSO): $\delta$ 7.20-6.70 (m, 10H, C-H, aromatic), $\delta 3.50$ (s, 3H, C-H, aliphatic), $\delta 1.30$ (s, 1H, SH). ${ }^{13} \mathrm{C}-\mathbf{N M R}$ (DMSO): $\delta 181.94$ (C-2); $\delta 173.93$ (C-4); $\delta 138.55$ (C-6); $\delta$ 129.13 (C-7) $\delta 128.89$ (C-8); $\delta 127.44$ (C-9); $\delta 71.76$ (C-5);

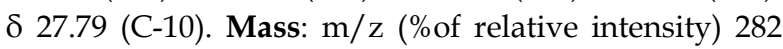
(M+100\%), 205 (22\%), 180(68\%), 165 (50\%), 121 (7\%), 104 $(72 \%), 77(49 \%), 59(6 \%), 51(17 \%), 39$ (3\%). The molecular ion peak appears at $\mathrm{m} / \mathrm{z} 282$ due to $\mathrm{C}_{16} \mathrm{H}_{14} \mathrm{~N}_{2} \mathrm{OS}$.

\section{Preparation of 1,3-dimethyl-5, 5-diphenyl-2-thiohy- dantoin (2c)}

Compound, $2 \mathrm{c}$ was obtained from benzil, $1 ;(1.00 \mathrm{~g}, 4.76$ $\mathrm{mmol} / \mathrm{L})$ and 1,3-dimethylthiourea; (1.00 g, $9.61 \mathrm{mmol} /$ L) in ethanol following the procedure of 1a. Compound 2c was obtained as white crystalline solids, m.p. $154-156^{\circ} \mathrm{C}$ having $0.950 \mathrm{~g}$, yielded $85 \%$. IR: $\mathrm{v}^{\mathrm{Nujol}}\left(\mathrm{cm}^{-1}\right)$ 3030 (s, vC-H aromatic); 2930, 2858 (s, vC-H, aliphatic); 1643 (s, vC=O amide); 1470, 1448 (s, vC=C, aromatic); 1296 (s, vC-N); 1126 (s, vC=S stretching vibration). ${ }^{1} \mathbf{H}-$ NMR (DMSO): $\delta$ 7.00-6.60 (m, 10H, C-H, aromatic), $\delta$ 3.30 (bs, 6H, CH 3 ). ${ }^{13} \mathrm{C}-\mathrm{NMR}$ (DMSO): $\delta 184.08$ (C-2, C-

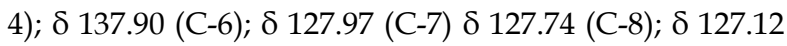

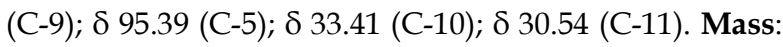
$\mathrm{m} / \mathrm{z}$ (\%of relative intensity) $296\left(\mathrm{M}^{+} .100 \%\right), 224(23 \%)$, 209(13\%), 176 (10\%), 154 (31\%), 136 (45\%), 105 (56\%), 91 $(13 \%), 77(14 \%), 43(12 \%)$. The molecular ion peak appears at $\mathrm{m} / \mathrm{z} 296$ due to $\mathrm{C}_{17} \mathrm{H}_{16} \mathrm{~N}_{2} \mathrm{OS}$.

Preparation of 1,3-diethyl-5, 5-diphenyl-2-thiohydantoin $(2 d)$

Refluxing of benzil, 1; (0.84 g, $4.00 \mathrm{mmol} / \mathrm{L})$ and 1,3diethylthiourea; $(1.06 \mathrm{~g}, 8.00 \mathrm{mmol} / \mathrm{L})$ and the following procedure of $1 \mathrm{a}$ gave the product $2 \mathrm{~d}$. The product was recrystallized in ethanol, m.p. $116-117^{\circ} \mathrm{C}$ having yielded $0.297 \mathrm{~g}, 45 \%$. IR: v Nujol $\left(\mathrm{cm}^{-1}\right) 3110(\mathrm{w}, \mathrm{vC}-\mathrm{H}$ aromatic); 2990, 2830 (s, vC-H, aliphatic); 1716 (s, vC=O amide, NPh-CO-C-Ph2); 1635 (s, vC=O amide, NPh-CO$\mathrm{NPh}) ; 1595,1541,1508$ (vC $=\mathrm{C}$, aromatic). 


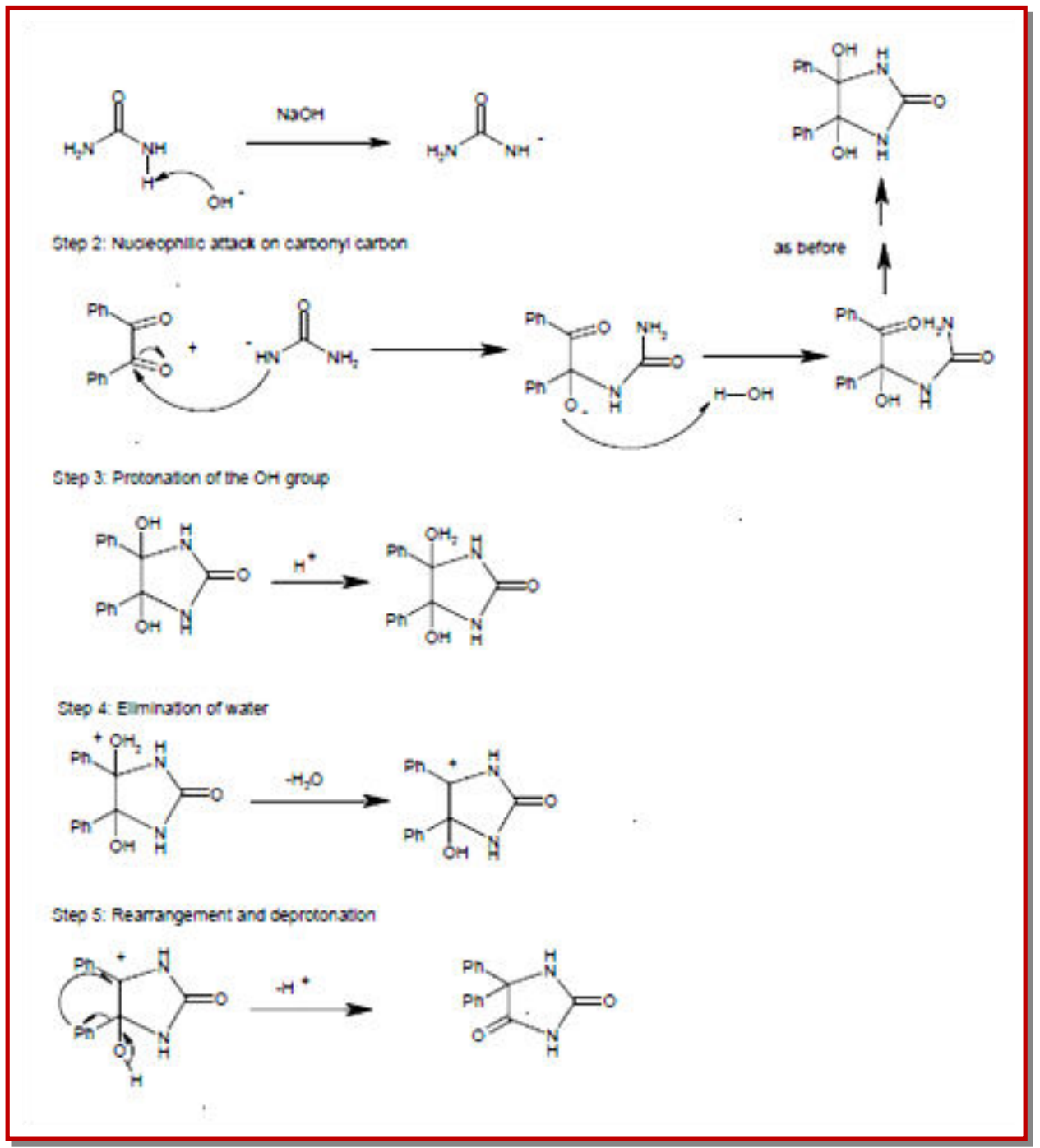

Scheme 2

${ }^{1}$ H-NMR (DMSO): $\delta$ 7.00-6.80 (m, 10H, C-H, aromatic), $\delta 3.60\left(\mathrm{q}, 2 \mathrm{H},{ }^{11} \mathrm{CH}_{2}\right), \delta 3.30\left(\mathrm{q}, 2 \mathrm{H},{ }^{13} \mathrm{CH}_{2}\right), \delta 1.20(\mathrm{t}, 6 \mathrm{H}$, $\mathrm{CH}_{3}$ ). ${ }^{13}$ C-NMR (DMSO): $\delta 183.31$ (C-2); $\delta 183.21$ (C-4); $\delta 140.07$ (C-6); $\delta 128.17$ (C-7); $\delta 127.97$ (C-8); $\delta 127.83$ (C9); $\delta 99.62$ (C-5); $\delta 96.54$ (C-11); $\delta 96.28(\mathrm{C}-13) ; \delta 14.85$ (C12); $\delta 14.43$ (C-14). Mass: $\mathrm{m} / \mathrm{z}$ (\% of relative intensity) 324 (M+12\%), 194 (28\%), 165(19\%), 150 (55\%), 121 (12\%), $105(100 \%), 86(9 \%), 77$ (50\%), 51 (5\%), 29 (21\%). The molecular ion peak appears at $\mathrm{m} / \mathrm{z} 324$ due to $\mathrm{C}_{19} \mathrm{H}_{20} \mathrm{~N}_{2} \mathrm{OS}$.

Preparation of S-methyl-5, 5-Diphenyl-2-thiohydantoin (2) (Muccioli et al., 2003)

The compound, 2a $(0.200 \mathrm{~g}, 0.71 \mathrm{mmol} / \mathrm{L})$ was dissolved in anhydrous DMF $(0.70 \mathrm{~mL})$ and $\mathrm{K}_{2} \mathrm{CO}_{3}(0.41$ $\mathrm{g}, 0.31 \mathrm{mmol} / \mathrm{L})$ then iodomethane $(0.70 \mathrm{~mL}, 0.71$ $\mathrm{mmol} / \mathrm{L}$ ) were added to this mixture and stirred overnight at room temperature. The mixture was poured into distilled water. The resulting precipitate was collected, dried and recrystallized from ethanol (If some of $\mathrm{K}_{2} \mathrm{CO}_{3}$ are non-reacted then hot ethanol solution of product is filtered to separate $\mathrm{K}_{2} \mathrm{CO}_{3}$ from the product) the product, 2 . The yields of the product, 2 were $0.75 \mathrm{~g}, 38 \%$ having m.p. $172-174^{\circ} \mathrm{C}$. IR: v ${ }^{\mathrm{Nujol}}\left(\mathrm{cm}^{-1}\right)$ 3240 (w, vN-H, amine); 3010 (s, vC-H, aromatic); 2900, 2855 (s, vC-H, aliphatic); 1725 (s, vC=O); 1684 (s, $\mathrm{vC}=\mathrm{N})$; 1585, 1506, 1489 (vC=C, aromatic). ${ }^{1} \mathbf{H}-\mathbf{N M R}$ (DMSO): $\delta$ 7.40-7.20 (m, 10H, C-H, aromatic), $\delta 3.20$ (s, $1 \mathrm{H}, \mathrm{NH}), \delta 2.70\left(\mathrm{~s}, 3 \mathrm{H}, \mathrm{C}-\mathrm{H}\right.$, aliphatic). ${ }^{13} \mathrm{C}-\mathrm{NMR}$ (DMSO): $\delta 180.36$ (C-2); $\delta 162.42$ (C-4); $\delta 140.80$ (C-6); $\delta$ 128.72 (C-7); $\delta 127.97$ (C-8); $\delta 127.14$ (C-9); $\delta 77.94$ (C-5); $\delta 26.87$ (C-10). Mass: $\mathrm{m} / \mathrm{z}$ (\%of relative intensity) 282 (M+.2\%) 176 (27\%), 165(12\%), 154 (100\%), 136 (70\%), 120 (13\%), 107 (19\%), 88 (18\%), 77 (15\%), 51 (5\%), 43 (8\%). 


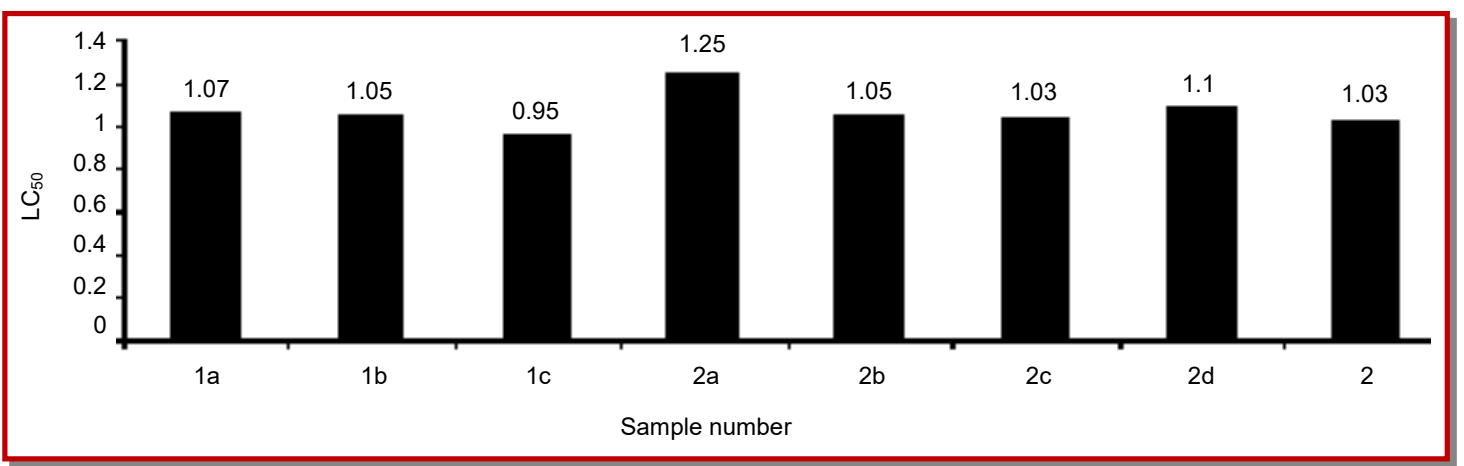

Figure 1: Comparative graphical representation of the $\mathrm{LC}_{50}$ of toxicity for the synthesized compounds against brine shrimp lethality test

The molecular ion peak appears at $\mathrm{m} / \mathrm{z} 282$ due to $\mathrm{C}_{16} \mathrm{H}_{14} \mathrm{~N}_{2} \mathrm{OS}$.

\section{Results and Discussion}

Simple base catalyzed condensation of benzil, 1 with urea, monophenyl urea and diphenyl urea in absolute ethanol furnished 1a, 1b, 1c whereas with thiourea, methyl thiourea, dimethyl thiourea and diethyl thiourea gave $2 a, 2 b, 2 c$ and $2 d$. The formation of these products follows the pinacole-pinacolone type (Shukla and Trivedi, 1997) rearrangement that is shown in the Scheme 2 (e.g., compound, 1a). The IR spectrum of the compound, 1a at $3271 \mathrm{~cm}^{-1}$ indicates the presence of $\mathrm{NH}$ group of amide moiety. The other band at $3204 \mathrm{~cm}^{-1}$ also indicates the presence of $\mathrm{NH}$ in $\mathrm{Ph}_{2} \mathrm{C}-\mathrm{NH}-\mathrm{CO}$. The clear band at $3055 \mathrm{~cm}^{-1}$ shows the presence of $\mathrm{C}-\mathrm{H}$ stretching vibration of phenyl ring. The lower absorption at 1772 $\mathrm{cm}^{-1}$ assigns $\mathrm{C}=\mathrm{O}$ group of amide in $\mathrm{Ph}_{2}-\mathrm{CO}-\mathrm{NH}-$, on the other hand the band at $1741 \mathrm{~cm}^{-1}$ corresponds to other $\mathrm{C}=\mathrm{O}$ group in NH-CO-NH. The bands at $1597 \mathrm{~cm}^{-}$ $1,1541 \mathrm{~cm}^{-1}, 1508 \mathrm{~cm}^{-1}$ give the strong support of $\mathrm{C}=\mathrm{C}$ stretching vibration of phenyl ring. ${ }^{1} \mathbf{H}-\mathbf{N M R}$ spectrum shows two singlets at $\delta 10.1$ and $\delta 9.1$, which would be assigned for $\mathrm{NH}$ proton of amide. The aromatic protons appear as multiplet at $\delta$ 7.8-7.0. ${ }^{13} \mathrm{C}-\mathrm{NMR}$ spectrum at $\delta$ 175.2 (C-4) and $\delta 156.4$ (C-2) is for the carbonyl groups of amide. The aromatic carbons are designated by the following values $\delta 140.3$ (C-6), $\delta 128.9$ (C-7), $\delta 128.4$ (C8), $\delta 126.9$ (C-9) and at $\delta 70.6$ (C-5). In the MS spectrum of the compound, 1a the molecular ion peak $\left(\mathrm{M}^{+} .3 \%\right)$ appears at $\mathrm{m} / \mathrm{z} 252$ that corresponding to the molecular formula $\mathrm{C}_{15} \mathrm{H}_{12} \mathrm{~N}_{2} \mathrm{O}_{2}$. In this spectrum the base peak is formed at $\mathrm{m} / \mathrm{z} 154$.

Methylation of $2 a$ with $\mathrm{CH}_{3} \mathrm{I}$ in the presence of $\mathrm{K}_{2} \mathrm{CO}_{3}$ in dry DMF gave the product (2)
In the IR spectrum of the compound, 2 the sharp band at $3240 \mathrm{~cm}^{-1}$ indicates the presence of $\mathrm{NH}$ group of amide. The signal at $3010 \mathrm{~cm}^{-1}$ locates the presence of C$\mathrm{H}$ stretching vibration in aromatic. The bands at 2900 $\mathrm{cm}^{-1}$ and $2855 \mathrm{~cm}^{-1}$ indicate the presence of $\mathrm{C}-\mathrm{H}$ group for $\mathrm{CH}_{3}$. The clear and sharp band at $1725 \mathrm{~cm}^{-1}$ is assigned for $\mathrm{C}=\mathrm{O}$ group. The band at $1684 \mathrm{~cm}^{-1}$ indicates the presence of $\mathrm{C}=\mathrm{N}$ group. The bands at 1585, 1506 and 1489 give the strong support for the presence of $\mathrm{C}=\mathrm{C}$ stretching vibration in the aromatic ring. In ${ }^{\mathbf{1}} \mathbf{H}-\mathbf{N M R}$ spectrum the aromatic protons appear as multiplet at $\delta$ 7.4-7.2. The singlet at $\delta 3.2$ indicates the presence of $\mathrm{NH}$ group and the singlet at $\delta 2.7$ is observed for $\mathrm{CH}_{3}$ group in $\mathrm{S}-\mathrm{CH}_{3}$. In ${ }^{13} \mathrm{C}-\mathbf{N M R}$ spectrum the signals at $\delta 180.4$ (C-2) and $\delta 162.4$ (C-4) appears for both $\mathrm{C}=\mathrm{S}$ and $\mathrm{C}=\mathrm{O}$ groups respectively. The aromatic carbons are designated by the following

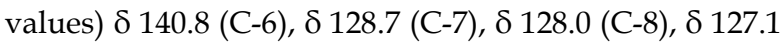
(C-9). The value at 77.9 (C-5) appears for the aliphatic carbon with various substituted groups. The signal at $\delta$ 26.9 (C-10) is concerned for simple aliphatic carbon $\mathrm{CH}_{3}$. In the MS spectrum the molecular ion peak $\left(\mathrm{M}^{+} \cdot 2 \%\right)$ appears at $\mathrm{m} / \mathrm{z} 282$ that corresponding to the molecular formula $\mathrm{C}_{16} \mathrm{H}_{14}-\mathrm{N}_{2} \mathrm{OS}$. In this spectrum the base peak is formed at $\mathrm{m} / \mathrm{z} 154$.

\section{Cytotoxicity}

Cytotoxicity of all the compounds was measured by brine shrimp lethality bioassay method. Cisplatin, a recognized anti-cancer drug was used as reference to compare the efficacy of the synthesized compounds. Compounds 1a, 1b, 1c, 2a, 2b, 2c, 2d and 2 showed potential cytotoxicity but compounds 1b, 1c, 2b, 2c and 2 that showed highly cytotoxic activity and compounds 1a, 2a, 2d showed relatively low cytotoxic activity. The $\mathrm{LC}_{50}$ values of the titled compounds are represented in the Figure 1. 


\section{Financial Support}

Self-funded

\section{References}

Anderson JE, Goetz CM, McLaughlin JL, Suffness M. Phytochemical analysis. Oxford University Press, $4^{\text {th }}$ ed. 1991, p 107.

Furniss BS, Hannaford AJ, Rogers V, Smith PWG, Tatehell AR. Vogel's Textbook of practical organic chemistry. Longman Press, $4^{\text {th }}$ ed., 1998, pp 734-35.

Islam MR, Khayer K, Mahmud MI. Reaction of isatin with 2aminothiophenol leading to spiroheterocyclic having anticancer activity. Jahangirnagar Univ J Sci. 2001a; 24: 17-22.
Islam R, Khayer K, Abedin MJ, Islam MR. Synthesis of (5-spiro (5'-methylisatin)-4-acetyl-2-(acetyla mino $\Delta^{2}-1,3,4$ thiadiazoline and 5-spiro (5'-methylisatin)-4-acetyl-2-(5'methylisatin-3'-hydrazineo)- $\Delta^{2}-1,3,4$-thiadiazoline. Indian J Chem. 2001b; 40B: 240-42.

Lingcon MH, Islam R, Khayer K, Islam MR. Cyclization of substituted indole-2-one-3-thiosemicarbazones to noble heterocyclic systems. J Bangladesh Chem Soc. 2001; 14: 12732.

Muccioli GG, Poupaert JH, Wouters J, Norberg B, Poppitz W, Scriba GKE, Lambert DM. A rapid and efficient microwaveassisted synthesis of hydantoins and thiohydantoins. Tetrahedron 2003; 59: 1301-07.

Shukla SP, Trivedi GL. Modern organic chemistry. $1^{\text {st }}$ ed. S. Chand and Company Ltd., 1997, p 40. 